\section{Histochemistry and immunolo- calisation of glucokinin in antidiabetic plants used in traditional Mexican medicine}

\author{
Guillermo Laguna-Hernández, \\ Carlos A. Río-Zamorano, \\ Itzel G. Meneses-Ochoa, \\ Alicia E. Brechú-Franco \\ Faculty of Sciences, National \\ Autonomous University of Mexico, \\ Coyoacán, Mexico
}

\begin{abstract}
Mexico is a megadiverse country that has 3600 to 4000 species of medicinal plants, of which approximately 800 are used to treat conditions related to diabetes mellitus (DM). DM is a chronic degenerative disease of energy metabolism that exists as two types: type 1 (DM1) and type 2 (DM2). DM is considered a public health problem that affects $7 \%$ of the Mexican population older than 20 years. DM is clinically controlled with hypoglycaemic drugs, alpha-glucosidase inhibitors, insulin secretion stimulants or the direct application of insulin. The hypoglycaemic effectiveness of specific molecules has been determined only for some medicinal plants in Mexico used to treat DM2. The presence of molecules called glucokinins, wich are similar to animal insulin molecules, has been reported in some plant species; glucokinins act as both growth factors and regulators of glucose metabolism in plants. Therefore, we hypothesized that the hypoglycaemic effectiveness of some of the popularly used species for the control of DM could be due to the presence of glucokinin, as reported
\end{abstract} for Bauhinia variegata.

The goal of this work was to use histochemistry to detect, the accumulation of protein that is immunocytochemically compatible with glucokinin in slide sections of hypoglycaemic species used as remedies for DM2. The top fourteen most used medicinal plants in Mexico were selected for study via microscopic sections. Proteins were histochemically detected using naphthol blue black and Johansen's quadruple stain, and the immunocytochemical correspondence of the proteins with glucokinin was investigated using an insulin antibody. All species studied reacted positively to proteins and glucokinin in the same structures. The presence of glucokinin in these structures and the corresponding hypoglycaemic effects are discussed in the context of the actions of other compounds.

\section{Introduction}

Globally, the prevalence of diabetes mellitus (DM) is increasing at an alarming rate. This chronic pathology severely affects human health and the quality of life. ${ }^{1}$ $\mathrm{DM}$ is a common metabolic disorder that affects approximately $2.8 \%$ of the world's population and is anticipated to reach $5.4 \%$ by 2025 . Herbal medicines have highly esteemed for a long time and thus have become a growing part of modern medicine. ${ }^{2}$ Diabetic populations originate in industrialised countries, but $65 \%$ of individuals with DM live in developing countries. In Mexico, approximately $10 \%$ of the population has DM, and $90 \%$ of estimated cases are type 2 DM (DM2). DM2 is the frequent in older adults and obese people. DM2 is the leading cause of death, causing $12 \%$ of total deaths. ${ }^{3}$ Acording to ethnobotanical research, Mexicans empirically uses between 150 and 269 species of plants for DM control, ${ }^{4}$ although there are approximately 500 species used from only a handful of families, including the Asteraceae (47 species), Fabaceae (27), Cactaceae (16), Solanaceae and Euphorbiaceae (10) and Lamiaceae (9). ${ }^{5}$ Plants are potential sources of hypoglycaemic drugs and are widely used in several traditional systems of medicine to prevent diabetes. ${ }^{1}$ Groups of chemical compounds related to the activity of these plants include polysaccharides, alkaloids, glycopeptides, terpenes, peptides, amines, steroids, phenolic compounds (flavonoids, polyphenols), coumarins, sulphur compounds, inorganic ions ${ }^{6}$ and glucokinins.

Collip ${ }^{8}$ discovered in plants a compound that functions similarly to insulin but differentiated this compound from insulin by naming it glucokinin; glucokinin exists in diverse organisms in addition to plants. Since 1980, insulin-like molecules have been found in bacteria, protozoa and fungi, ${ }^{9}$ as well as in spinach leaves (Spinacia oleracea), water lentil (Lemma gibba) $)^{10}$ and maize (Zea mays). ${ }^{11}$ Because herbal recipes used to treat DM2 can be mixtures of various medicinal species, several mechanisms of action are involved in the hypoglycaemic control of plant origin. ${ }^{12}$ Some of the groups of chemical compounds related to the activity of these plants are polysaccharides, alkaloids, glycopeptides, terpenes, peptides, amines, steroids, phenolic compounds (flavonoids, polyphenols), lipids, coumarins, sulphur compounds and inorganic ions. The mecha-
Correspondence: Alicia Enriqueta BrechúFranco, National Autonomous University of Mexico, Faculty of Sciences, Av. Universidad 3000, Cd. Universitaria, Coyoacán, 04510 Mexico City, Mexico.

Tel. +52.55.56225431 - Fax: +52.55.56224828.

E-mail: aliciae@ciencias.unam.mx

Key words: Hypoglycaemic plants; diabetes mellitus; glucokinin; histochemistry; immunolocalisation; Mexican herbal medicine.

Contributions: CARZ, IGMO, worked on the preliminary research reports about the studied plants and the technique establishment, such as fixations, the cutting and staining, of plant organ samples, and the photographic register of the results; GLH, AEBC, interpreted the results and worked on the discussion, formatted the manuscript as an article with figures that illustrated the results.

Conflict of interest: the authors declare no conflict of interest.

Received for publication: 21 February 2017. Accepted for publication: 29 May 2017.

This work is licensed under a Creative Commons Attribution-NonCommercial 4.0 International License (CC BY-NC 4.0).

(C) Copyright G. Laguna-Hernándezet al., 2017 Licensee PAGEPress, Italy

European Journal of Histochemistry 2017; 61:2782 doi:10.4081/ejh.2017.2782

nisms involved in the activity of these compounds in glycaemia include competitive direct antagonism with insulin, stimulation of insulin secretion, stimulation of hepatic glycogenesis and glycolysis, adrenomimicry, blockage of the $\mathrm{K}^{+}$channels of pancreatic beta cells, stimulation of cyclic adenosine monophosphate (cAMP) and modulation of glucose uptake from the intestine. ${ }^{6}$ An insulin-like protein in the inner layer of the Canavalia ensiformis seed coat that has the same molecular mass and amino acid sequences as bovine insulin was reported..$^{13}$ Glucokinin has been detected in the seed coat in the legume Vigna unguiculata using both solid-phase adsorption-based enzymelinked immunosorbent assay (ELISA) with human anti-insulin antibodies and reversephase high-performance liquid chromatography (RP-HPLC); glucokinin and human insulin showed similar patterns. ${ }^{14}$ Using immunohistochemistry, immunocytochemistry and transmission electron microscopy, Azevedo et al. ${ }^{15}$ revealed the presence of glucokinin in the leaves of Bauhinia variegata; glucokinin was found mainly in chloroplasts and associated with calcium oxalate crystals. 
Glucose concentration in the blood decreased in diabetic rats when $B$. variegata was administered subcutaneously. Moreover, orally administered butanol extract from the leaves of Bauhinia forficata significantly reduced blood glucose levels in diabetic rats. ${ }^{7}$ Glucokinin may be involved in the biosynthesis and transport of carbohydrates. ${ }^{14}$ Therefore, glucokinin may act in the growth and development of plants and in the production of starch in via a process similar to the biosynthesis of glycogen in the liver, in which insulin is involved. ${ }^{16}$ Glucokinin functions similarly to insulin and is present in plants; therefore, glucokinin may be responsible for the hypoglycaemic effect of plants used for the control of DM2.

The goal of this work was to detect using histochemical and immunolocalisation techniques the presence of glucokinin combined with accumulated protein in the parts of plant species used for the control of DM2 or those reported as hypoglycaemic.

\section{Materials and Methods}

\section{Species and organs of study}

Of the species of Mexican herbal medicines used to treat DM2,4,5 we selected the following plants (alphabetically ordered by the family to which the species belongs and the structure used in parentheses):

Petroselinum crispum (Mill.) Mansf., Apiaceae, 'Perejil' and 'Parsley' (leaf);

Bidens pilosa L., Asteraceae, 'Romerito blanco', 'Mozote', 'Acahual', 'Aceitilla' 'Beggar's Ticks', 'Blackjack', and 'Hairy beggartick' (leaf);

Brickellia cavanillesii (Cass.) A. Gray, Asteraceae, 'Prodigiosa' (leaf);

Cynara scolymus L., Asteraceae, 'Alcachofa', 'Alcachofera', 'Alcanfora', and 'Artichoke' (bract);

Taraxacum officinale Weber ex F H Wigg., Asteraceae, 'Árnica de diente', 'Diente de león', 'Chicoria', and 'Dandelion' (leaf);

Parmentiera aculeata (Kunth) L.O. Williams, Bignoniaceae, 'Cuajilote', 'Cuaxilotl', and 'Chote' (fruit);

Tecoma stans (L.) Juss. ex Kunth, Bignoniaceae, 'Tronadora', 'Alacrancillo', 'Nextamalxochitl', and 'X-k'anlol' (leaf);

Opuntia ficus-indica (L.) Mill., Cactaceae, 'Nopal' (cladode);

Beta vulgaris L., Chenopodiaceae, 'Betabel', 'Remolacha', and 'Beetroot' (leaf);
Aloe vera (L.) Burm.f., Liliaceae, 'Sábila' (leaf);

Guazuma ulmifolia Lam., Malvaceae, 'Guásima' and 'Cuaulote' (leaf);

Rubus adenotrichus Schltdl., Rosaceae, 'Zarza' and 'Zarzamora' (leaf);

Buddleja cordata Kunth, Scrophulariaceae, 'Tepozán' (leaf);

Cecropia obtusifolia Bertol., Urticaceae, 'Guarumbo' and 'Kooché' (leaf).

\section{Reagents and equipment \\ Fixatives}

FAA $(10 \%$ formaldehyde $/ 5 \%$ acetic acid $/ 50 \%$ alcohol) (Merck, S.A. de C.V., Naucalpan de Juárez, Mexico).

$10 \%$ formaldehyde in $0.1 \mathrm{M}$ sodium cacodylate buffer, $\mathrm{pH}$ 7.4. (Electron Microscopy Science ${ }^{\circledR}$, IACCSA, Tlalpan, Mexico).

AGF (1.5\% acrolein/3\% glutaraldehyde $/ 1.5 \%$ formaldehyde in $0.1 \mathrm{M}$ sodium cacodylate buffer, pH 7.4 (Electron Microscopy Science ${ }^{\circledR}$ ).

\section{Dyes}

Naphthol blue black (NBB), Fast Green, Orange G, safranine, crystal violet (SigmaAldrich Co., Milwaukee, WI, USA).

Starr Trek Universal HRP Detection System ${ }^{\circledR}$ Kit (Biocare Medical ${ }^{\circledR}$, Biocare Mexico, Tlalpan, Mexico).

Polyclonal guinea pig anti-swine insulin (Dako, Glostrup, Denmark).

\section{Equipment}

HM 340E Rotary Microtome (MICROM GmbH, Walldorf, Germany). Images were collected using a Canon Power Shot A640 digital camera coupled to a Zeiss Axiostar Microscope with AxioVision (Carl Zeiss de México S.A. de C.V. Coyoacán, Mexico)

\section{Procedures}

\section{Fixation}

Plant samples were cut into 2- to 5-mm pieces and were fixed as mentioned above.

Mouse pancreas served as a positive control. The pancreas was rinsed with $0.9 \%$ $\mathrm{NaCl}$ solution until blood was removed. The pancreas was then fixed in $10 \%$ formaldehyde and buffered with $0.1 \mathrm{M}$ sodium cacodylate ( $\mathrm{pH}$ 7.4).

After fixation, each material was washed with tap water, dehydrated in an alcohol series, infiltrated and included in Paraplast ${ }^{\circledR}$. Ten micrometre-thick sections were obtained for each material and transferred to slides that were progressively numbered until 10 of each organ of the species that was obtained.

\section{Histochemistry}

The sections were processed by comparing similar zones between each technique using alternating slides of progressive numbering. Comparisons were made in duplicate. NBB histochemistry ${ }^{17}(1.0 \%$ NBB in $50 \%$ ethanol). for protein analysis was applied to the first and second slides of each plant organ. For the immunolocalisation technique, we used slides three and four for the positive reaction and slides five and six for the negative control. Some slides were processed using Johansen's quadruple stain $^{18}$ to verify the detection of protein or special structures.

\section{NBB stain}

For this protocol, we used NBB instead of aniline blue black, which was used by Fisher. ${ }^{17}$ Briefly, slides were reduced to $70 \%$ alcohol. Slides were then stained with a $1 \% \mathrm{NBB} / 50 \%$ alcohol solution for $5 \mathrm{~min}$. After rinsing briefly in $96 \%$ alcohol followed by $100 \%$ alcohol, the slides were rinsed briefly with n-butanol. Finally, the slides were rinsed twice in xylol and then mounted on balsam.

\section{Johansen's quadruple stain}

This method correlates stain affinity with specific structures as closely as possible and uses more recently developed stain solvents, such as Orange G, methyl violet 2B, Methyl Cellosolve, tertiary butyl alcohol, clove oil and glacial acetic acid. The staining is simple, even if mixtures are complex; differentiation is automatic and little personal judgement is needed. ${ }^{18}$

\section{Immunolocalisation}

The sections of plant organs and mouse pancreas needed for this technique were deparaffinised, rehydrated and processed according to the manufacturer's instructions; however steps 3 (incubation with Carezyme II at $37^{\circ} \mathrm{C}$ for $5 \mathrm{~min}$ ) and 14 (application of drops of CAT haematoxylin for $1 \mathrm{~min}$ ) were omitted because Carezyme II degrades the section or detaches them from the slide, and the purple colour of the reaction of CAT haematoxylin with the cytoplasm and nuclei masks the positive reaction of the antibody. A negative control was used for each species that did not receive insulin antibodies.

Insulin immunolocalisation was performed using the Starr Trek Universal HRP Detection System ${ }^{\circledR}$ Kit, Control Number: 901-STUHRP700-090314, ISO 9001 \&13485 Certified. Refer to the National Committee for Clinical Laboratory Standars Quality Assurance for Immunocytochemistry approved guidelines (Vol. 19, No. 26, 
December 1999, MM4-A).

The sections were washed with peroxidase for $5 \mathrm{~min}$ to remove the endogenous peroxide and then covered with the primary antibody for $60 \mathrm{~min}$. Excess antibodies were removed, after which the link reagent was applied for $10 \mathrm{~min}$. Streptavidin-HRP was then applied for $10 \mathrm{~min}$, and the sections were dehydrated in $100 \%$ ethanol and xylene for covering with resin.

\section{Results}

All fixation treatments worked well for both histochemical staining and glucokinin immunolocalisation, although the material fixed in FAA showed the best response of all three techniques. Histochemistry using NBB is a specific technique for proteins; in general, NBB stains blue the cell walls of the epidermis and its derived structures, such as trichomes, cellular contents, the chloroplasts of mesophyll parenchyma, and neighbouring cells of the vascular bundle, which may correspond to laticiferous or secretory canals, depending on the species. In the particular description of the positive reaction using this technique for each species, the zones of protein accumulation or strong reaction are highlighted and compared with those resulting from immunolocalisation. Only one figure based on the reactions with Johansen's quadruple stain is presented that illustrates the association with protein (purple or violet colour in the same zone) (Figure 1L).

\section{Immunolocalisation}

The positive reaction effecting brown/reddish colour corresponds to the complex formed by the antibody against insulin from the pancreas or glucokinin from plant organs. In the mouse pancreas sections, a positive response was observed only in the beta cells of the islets of Langerhans (Figure 1A). The results based on this technique for the plant organ sec- tions corresponded to those of the NBB histochemical technique, and the negative control of the immunolocalisation did not exhibit this reaction (Figure 1 B-D).

\section{Sections of the organs of the species studied}

\section{P. crispum (leaf)}

This section showed a strong reaction to NBB and immunocytochemistry, particularly in cells associated with vascular bundles and laticifers (Figure 1 B-D).

\section{B. pilosa (leaf)}

A positive reaction of immunolocalisation and NBB was observed in the cell walls of trichomes and vascular bundle fibres (Figure $1 \mathrm{E}, \mathrm{F}$ ).

B. cavanillesii (leaf)

This section had secretory canals and laticifers that were adjacent to vascular bundles and contained protein that reacts positively with the immunolocalisation technique. There were also reactions observed in glandular trichomes (Figure $1 \mathrm{G}, \mathrm{H}$ ).
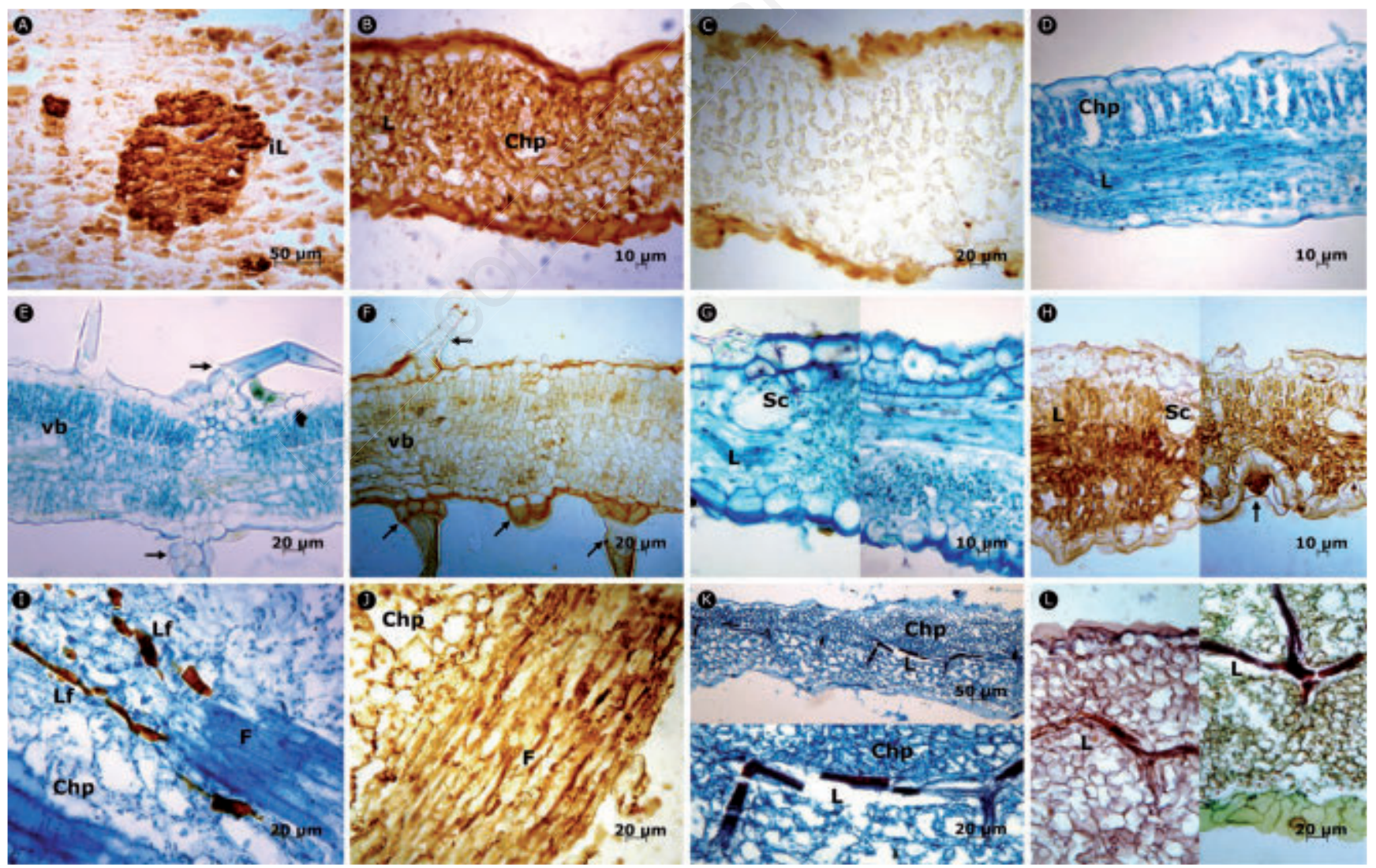

Figure 1. A) Positive control mouse pancreas, islet of Langerhans. B-D) P. crispum. E, F) B. pilosa. G,H) B. cavanillesii. I,J) C. scolymus. $\mathrm{K}, \mathrm{L})$ T. officinale. $\mathrm{L}$ ) The reaction of Johansen's quadruple stain is shown compared with that of immunocytochemistry. The positive reaction of immunocytochemistry is shown in brown/reddish colour. The negative control of immunocytochemistry is colourless (C). The positive reaction of NBB is blue. iL, islet of Langerhans; L, laticifers; Chp, chlorophyll parenchyma; vb, vascular bundle; Sc, secretory canal; Lf, laticifer with phenols; F, fibres; arrows, trichomes. 
C. scolymus (bract)

A positive reaction to NBB was detected, which corresponds to the positive reaction to immunocytochemistry in chloroplasts and the cell walls of fibres located in the parenchyma. Phenolic laticifers were observed in the surrounding areas (Figure 1 I, J).

T. officinale (leaf)

Laticifers were observed that were adjacent to vascular bundles and contained abundant protein. This protein strongly positively reacted with immunolocalisation and reacted in the mesophyll (Figure $1 \mathrm{~K}, \mathrm{~L}$ ).

$P$. aculeata (fruit)

A strong, positive reaction to NBB was observed in epidermal and subepidermal cells as well as in fibres of the mesocarp parenchyma, which corresponded to the weak positive reaction of immunolocalisation (Figure 2 A,B).

T. stans (leaf)

Laticifers were discovered that were adjacent to the vascular bundles and contained protein that reacted positively with immunolocalisation. An intense positive reaction of histochemistry and immunocy- tochemistry was also observed in some epidermal cells, in trichomes and in mesophyll cells (Figure 2 C,D).

O. ficus-indica (cladode)

A positive reaction with NBB that corresponded to immunocytochemistry was strongly present in the multilayer epidermis and in the contents of mucilage-secreting cavities. An abundance of cells with crystals was observed in epidermal and parenchyma tissue (Figure 2 E-G).

B. vulgaris (leaf)

Laticifers adjacent to the vascular bundles contained protein that reacted positively with immunolocalisation and many adjacent mesophyll cells contained crystals (Figure $2 \mathrm{H}-\mathrm{K}$ ).

A. vera (leaf)

This section showed the same protein localisation with both techniques; the reaction was intense in the cell walls of the epidermis, in mesophyll chloroplasts and in the mucilage (gel) of secretory canals (Figure 3 A-D).

G. ulmifolia (leaf)

Two types of laticifers were observed that were adjacent to the vascular bundles: laticifers with orange/gold tannins and others containing protein. NBB and immunocytochemistry detected strong reactions in the mesophyll and laticifers with protein, which closely matched the sections of the negative control (Figure $3 \mathrm{E}-\mathrm{H}$ ).

\section{R. adenotrichus (leaf)}

NBB and immunocytochemistry produced strong, positive reactions in laticifers, trichomes and chlorophyll parenchyma (Figure $3 \mathrm{I}, \mathrm{J})$.

\section{B. cordata (leaf)}

Articulated laticifers were observed to be associated with vascular bundles. These laticifers reacted strongly to both NBB and immunocytochemistry; some parenchyma cells had crystals (Figure $3 \mathrm{~K}-\mathrm{M}$ ).

C. obtusifolia (leaf)

Both the tannin content throughout the leaf mesophyll and the observed greyish cystoliths were highlighted. NBB and immunocytochemistry strongly positively reacted in the chlorophyll parenchyma and subepidermal cells, where tannins are also located (Figure $3 \mathrm{~N}, \mathrm{O}$ ).
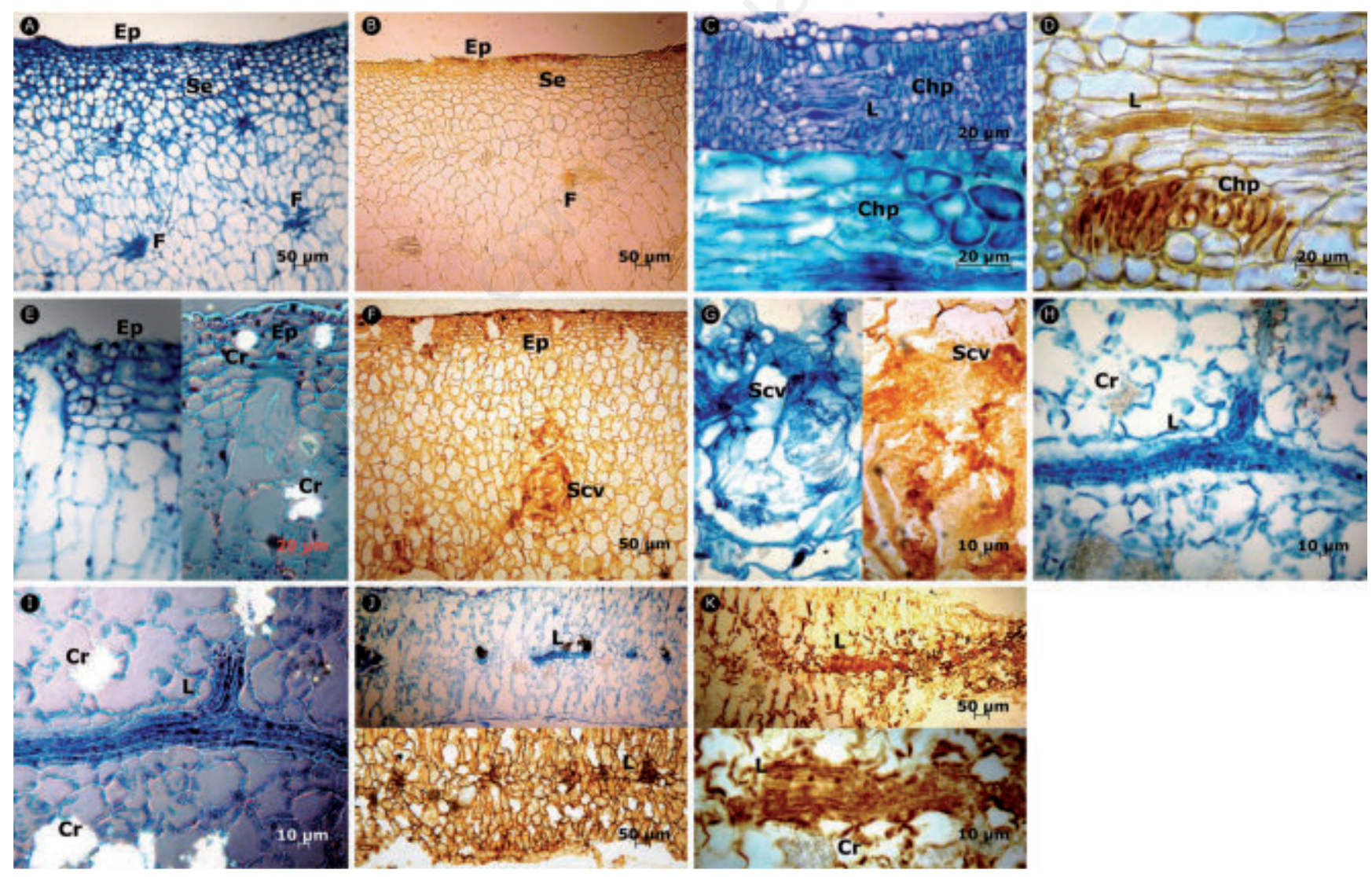

Figure 2. A, B) P. aculeata. C, D) T. stans. E-G) O. ficus-indica. H-K) B. vulgaris. E, I and $\mathrm{K}$ were imaged with phase contrast microscopy to highlight crystals. Ep, epidermis; Se, sub-epidermis; Cr, crystals; L, laticifers; Chp, chlorophyll parenchyma; Scv, secretory cavity; F, fibres. 


\section{Discussion}

Johansen's quadruple stain effectively corroborated the presence of protein via purple or violet colour in the same zones of reactions to NBB and immunocytochemical techniques (Figure 1L). This method brilliantly stains plant tissue more than clearly any other stain does. ${ }^{19}$ Patients with DM2 share a pathophysiology that involves pancreatic beta cells, the liver, and peripheral target tissues such as skeletal muscle and adipose tissue. Insulin resistance is a core defect in DM2 and may be a primary factor in the development of atherosclerotic cardiovascular disease and other components associated with metabolic syndrome. ${ }^{20}$ Only a few reports on the hypoglycaemic activity of medicinal plants used to treat DM2 in Mexico have confirmed the hypoglycaemic effectiveness of specific molecules in some of the mechanisms of glucose metabolism control that also help in restoring it; the following are examples of this hypoglycaemic effectiveness:

- Petroselinum crispum aqueous extract protects against hepatotoxicity caused by diabetes. ${ }^{21}$ The extract is effective as a hypoglycaemic treatment in rats with diabetes due to its ascorbic acid, flavonoids and essential oils. ${ }^{22}$

- Bidens pilosa stimulates insulin secretion, protects the islets of Langerhans and increases blood insulin levels; ${ }^{23}$ the hypoglycaemic effectiveness of this plant is due to the presence of acetylenic glycosides in the aqueous extract of the aerial portion. ${ }^{24-26}$
The effect of $B$. pilosa formulations on fasting blood glucose (FBG), fasting serum insulin, and glycosylated haemoglobin A1c $(\mathrm{HbA} 1 \mathrm{c})$ in diabetic subjects was evaluated. The $B$. pilosa formulations reduced FBG and $\mathrm{HbAlc}$ in diabetics but increased fasting serum insulin in healthy subjects. Moreover, the combination of the $B$. pilosa formulation with antidiabetic drugs resulted in better glycaemic control in diabetics. The homeostatic model assessment (HOMA) data suggested that the antidiabetic activity of this formulation occurred via improvement of beta-cell function. The safety of the B. pilosa formulation in healthy subjects was also tested, but no obvious side effects were observed, which indicates that $B$. pilosa is a potential antidiabetic treatment. ${ }^{27}$ In our study, $B$. pilosa samples did not result
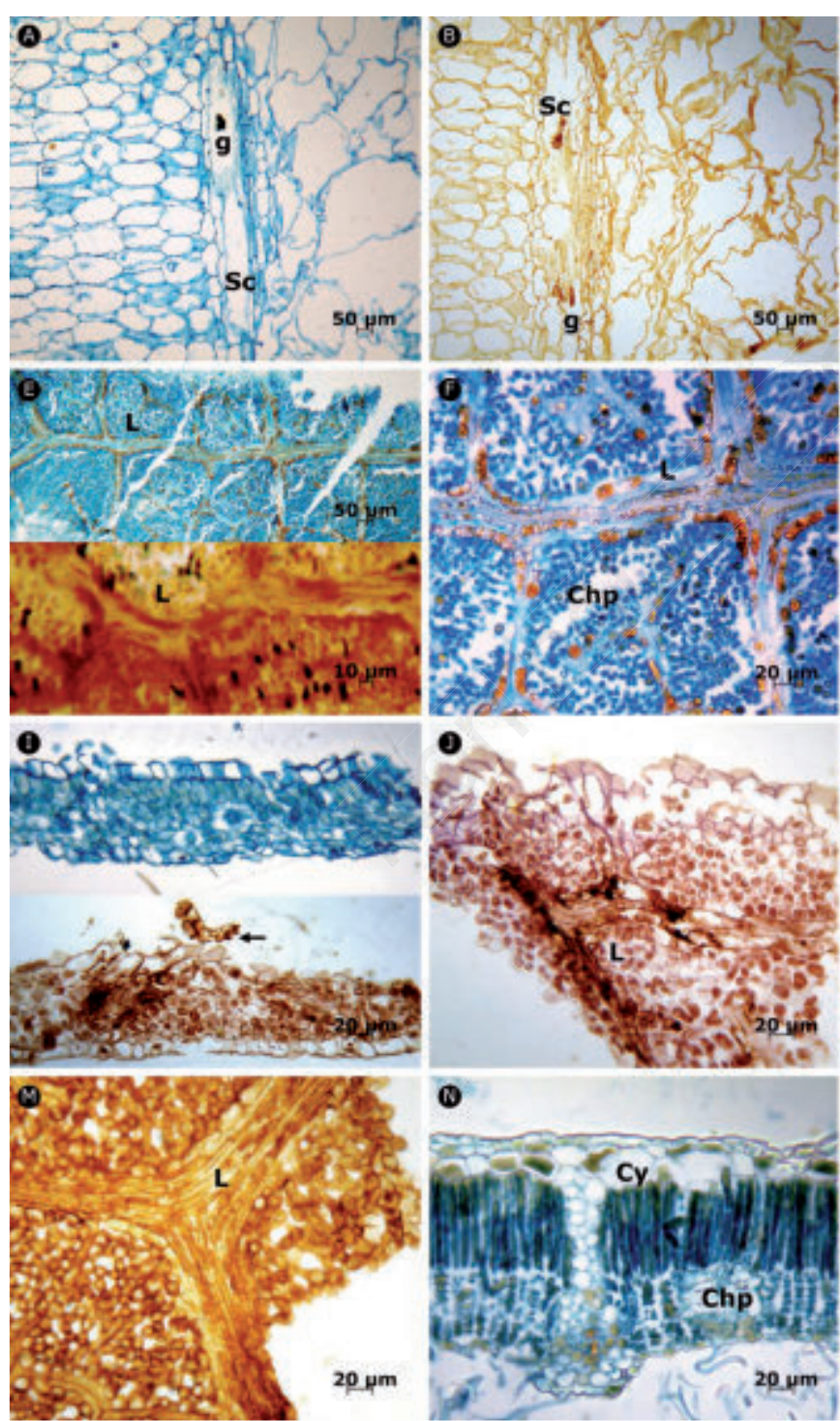
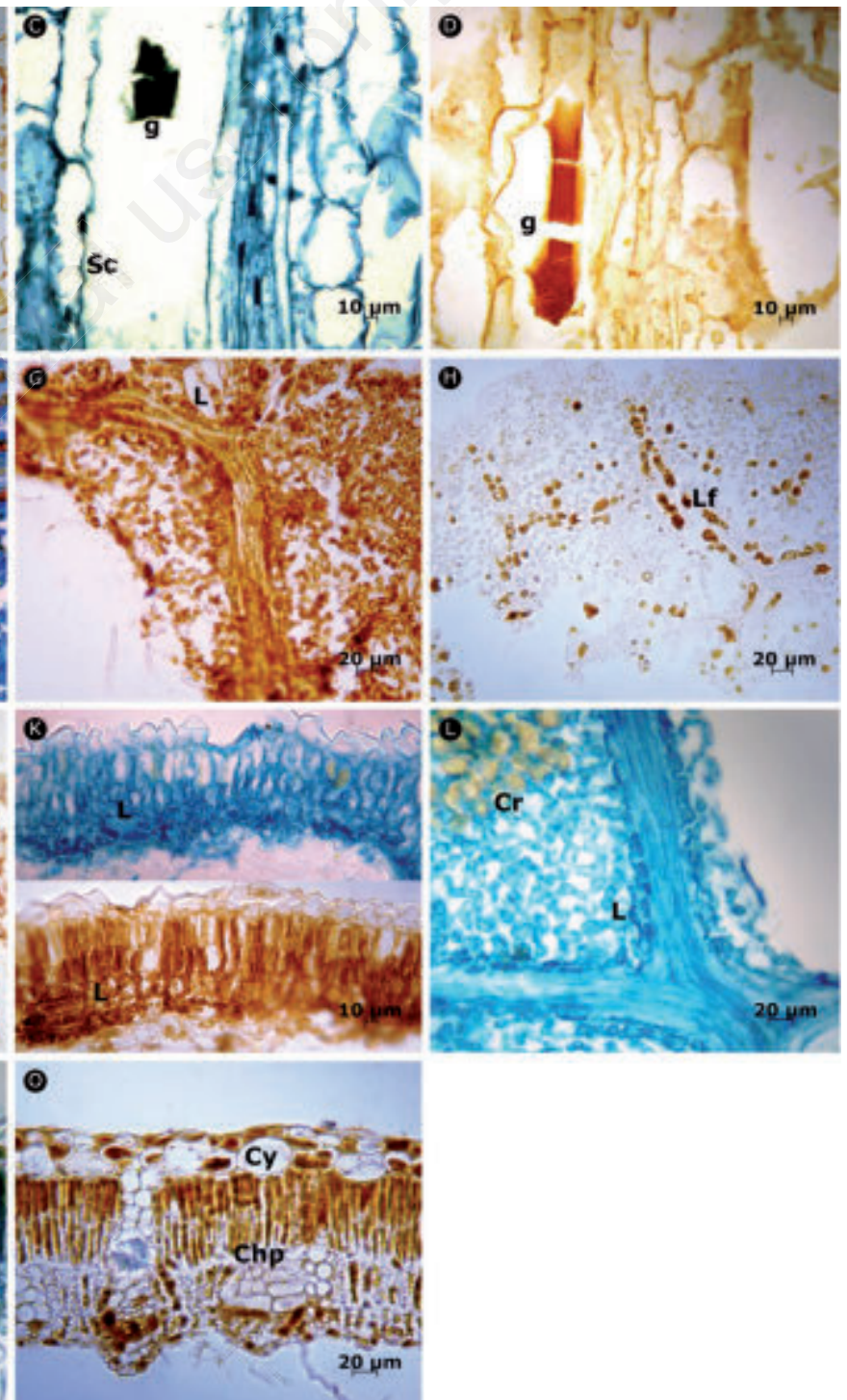

Figure 3. A-D) A. vera. E-H) G. ulmifolia. I, J) R. adenotrichus. K-M) B. cordata. N, O) C. obtusifolia. Cr, crystals; L, laticifers; Chp, chlorophyll parenchyma; Sc, secretory canal; g, gel; Cy, cystoliths. 
in a strong immunocytochemical reaction to glucokinin; therefore, its hypoglycaemic effect is most likely due to the reported metabolites such as cytopiloyne and related polyynes (3- $\beta$-D-glucopyranosyl-1hydroxy-6(E)-tetradecene-8,10,12-triyne and (R)-3,5,7,9,11-tridecapentayne-1,2diol), which are anti-diabetics in animal models. ${ }^{26,28}$ The data therefore reveal a new biological action of polyynes. Interestingly, 34 polyynes have been reported in B. pilosa. Whether all the polyynes present in this plant have antidiabetic activities remains unclear. ${ }^{26,29}$

- Brickellia cavanillesii, C. scolymus, T. stans and C. obtusifolia, have hypoglycaemic effectiveness due to the inhibition of alpha-glucosidase. .,30-36 $^{-30}$

- Brickellia cavanillesii has hypoglycaemic effectiveness due to the high activity of metabolites such as 6-hydroxyacetyl-5hydroxy-2,2-dimethyl-2H-chromene, sesquiterpene lactone (calein $\mathrm{C}$ ), the flavonoid isorhamnetin, and quercetin. The aqueous extract of $B$. cavanillesii is effective for controlling fasting and postprandial high blood glucose levels in diabetic mice. ${ }^{33}$ The effectiveness of $B$. cavanillesii has also been reported in transversal, descriptive, and comparative studies in humans. ${ }^{37}$ Due to the strong reaction of glucokinin in laticifers, secretory canals and chlorophilic parenchyma, glucokinin could be expected to be a contributor of insulin as well as an inhibitor of alpha-glucosidase, which would make the plant traditionally effective for the treatment of DM2.

- Cynara scolymus is a medicinal plant rich in cynarin and orthophenole. Hinou ${ }^{38}$ identified other various phytochemicals in globe artichoke such as cynaropicrin and sesquiterpene lactones that show both hypoglycaemic and hypolipidaemic activity. Nazni $^{39}$ reported that diabetic individuals $(\mathrm{N}=15)$ supplemented with 4 globe artichoke wheat biscuits containing $6 \mathrm{~g}$ of globe artichoke powder distributed daily as a snack to each individual [morning (2) and evening (2)] had a positive impact on the reduction of fasting and post-prandial blood glucose levels. The major constituents of artichoke extracts are hydroxycinnamic acids such as chlorogenic acid, dicaffeoylquinic acid, caffeic acid and ferulic acid and flavonoids such as luteolin and apigenin glycosides. In vitro studies using cultured rat hepatocytes have indicated hepatoprotective functions, and in vivo studies have shown the inhibition of cholesterol biosynthesis in human subjects. ${ }^{40}$ According to these metabolites, ${ }^{41-43}$ the antihyperglycaemic activity may be due to the inhibition of alpha-glucosidase as in C. obtusifolia.
Additionally, glucokinin does not contribute significantly to this benefit because glucokinin was located only in the cell walls of fibres of vascular bundles and in the chlorophilic parenchyma.

- Taraxacum officinale effectiveness as a hypoglycaemic agent in rats and rabbits is due to the increased secretion of insulin. ${ }^{44}$ The promising activity of the insulin secretagogue from various plant extracts at 1,10 , 20 and $40 \mu \mathrm{g} / \mathrm{mL}$ was observed for insulin release from INS-1 cells; T. officinale showed effects at $40 \mu \mathrm{g} / \mathrm{mL}(\mathrm{P}<0.05) .{ }^{45} \mathrm{In}$ addition, the increased oxidation of glucose in non-obese diabetic mice was reported using plant extract P-9801091, which is an antihyperglycaemic herbal preparation containing $9.7 \%$ T. officinale. ${ }^{46,47}$ The therapeutic actions of species have been attributed in part to their bitter constituents - specifically, sesquiterpenes typical of Compositae. In the extracts of $T$. officinale Weber roots, sesquiterpenes including the eudesmanolides tetrahydroridentin B and taraxacolide$O$-beta-glucopyranoside; the guaianolides 11beta,13-dihydrolactucin and ixerin D; and three germacranolide esters, taraxinic acid beta-glucopyranoside, and its 11,13dihydro derivative, as well as ainslioside. Other constituents isolated from dandelion roots ( $T$. officinale) included various triterpenes and phytosterols, such as taraxasterol; $\psi$-taraxasterol; their acetates; and their 16hydroxy derivatives arnidol and faradiol, alpha- and beta-amyrin, beta-sitosterol, beta-sitosterol-beta-D-glucopyranoside and stigmasterol. ${ }^{42,48-50}$

- Parmentiera aculeata has hypoglycaemic effectiveness, but its mechanism of action is unknown. The hypoglycaemic agent lactucin-8-O-methylacrylate (guaianolide) has been reported in Parmentiera edulis DC (synonymous with $P$. aculeata). ${ }^{51}$ The administration of chloroform extract of $P$. edulis to both normoglycemic and diabetic mice as well as to diabetic rats corroborated its high hypoglycaemic effectiveness. ${ }^{51,52}$ The presence of glucokinin in this species does not contribute significantly to its antihyperglycaemic effect.

Tecoma stans contains tecomine and tecostanine alkaloids. ${ }^{34}$ The aqueous extracts of $T$. stans in a glucose tolerance study with tolbutamide significantly reduced blood glucose levels because this plant extract also participates in the production of insulin. ${ }^{35}$ The alcoholic extract is more effective than the aqueous extract at lowering blood glucose levels due to the flavonoids and terpenes in the leaves of the species. ${ }^{36}$ The considerable amounts of glucokinin suggests that it contributes to hypoglycaemic activity.
- Opuntia ficus-indica. Several species of Opuntia are the most used and studied plants as antidiabetic remedies in Mexico, and these plants have already undergone clinical studies. ${ }^{34}$ The antihyperglycaemic effect of Opuntia streptacantha has been confirmed; this effect is not due to action on alpha-glucosidases and is not related to the intestinal hydrolysis of disaccharides. ${ }^{53-55}$ The abundance of glucokinin in the mucilage-secreting cavities may indicate that the effectiveness of $O$. ficus-indica (Nopal) in the popular treatment of DM2 in Mexico is specifically due to this molecule. This idea is supported by the abundance of crystals in epidermal and parenchimal cells in B. variegata. ${ }^{15}$

- Beta vulgaris. The extract of this plant protects the liver in patients with DM; ${ }^{56}$ the chard extract might improve the glucose response by increasing GLUT2 through Akt 2 and antioxidant defences in the liver, ${ }^{57}$ regenerating pancreatic beta-cells and increasing insulin secretion. ${ }^{58,59}$ The primary phenolic fraction (P2) components were vitexin-2'O-rhamnoside, its demethylated form 2'-xylosylvitexin, isorhamnetin 3gentiobioside, and rutin. $\mathrm{P} 2$ in toto and the individual components were characterised for their antioxidant capacity. ${ }^{60}$ The presence of glucokinin in laticifers and its association with crystal deposits in this species may contribute to the hypoglycaemic effectiveness of this plant.

- Aloe vera and G. ulmifolia, have hypoglycaemic effectiveness by decreasing insulin resistance. ${ }^{61,62}$

- Aloe vera. The effects of processed Aloe vera gel (PAG) on the course of established diet-induced non-insulin-dependent DM (NIDDM) were studied in C57BL/6J mice; the oral administration of PAG prevented the progression of NIDDM-related symptoms in high-fat diet-fed mice, which suggests that PAG could be useful for treating NIDDM. ${ }^{61}$ Tanaka et al. ${ }^{63}$ proposed that the antihyperglycaemic effect of the gel is due to the phytosterols lophenol, 24-methyllophenol, 24-ethyl-lophenol, cycloartanol and 24-methylene-cycloartanol. El Sayed et $a l .{ }^{64}$ attributed the hypoglycaemic activity of Aloe to both the gel polysaccharides and the phenol aloesin. On the other hand, standardised aloe preparations offer an attractive alternative for reverting the impaired fasting glucose and impaired glucose tolerance observed under conditions of prediabetes/metabolic syndrome, ${ }^{65}$ and aloe gel may be a safe antihyperglycemic and antihypercholesterolemic agent for hyperlipidaemic DM2 patients. ${ }^{66}$

- Guazuma ulmifolia exerts its antidiabetic effects by stimulating glucose uptake in 
both insulin-sensitive and insulin-resistant adipocytes without inducing adipogenesis. ${ }^{62}$ In oral glucose tolerance tests in alloxaninduced diabetic mice, aqueous leaf extracts of G. ulmifolia Lamk. significantly reduced plasma glucose levels, compared with those of the positive control, which suggests a potential antidiabetic effect. ${ }^{67}$ The strong immunocytochemical reaction to glucokinin in chlorophilic parenchyma and laticifers suggests that glucokinin of this species also contributes to the antihyperglycaemic and hypoglycaemic activity.

- Rubus adenotrichus. No pharmacological reports for $R$. adenotrichus exist, but antihyperglycaemic effects that rescued blood glucose in diabetic rats in other Rubus species have been reported, such as in Rubus ulmifolius ${ }^{68}$ and $R$. imperialis, due to alloxan and streptozotocin and to alloxan, respectively. ${ }^{69,70}$ Alloxan from Rubus fruticosus reduced blood glucose in both normal and diabetic rabbits, ${ }^{71}$ and this hypoglycaemic effect was extrapancreatic. ${ }^{72}$ Triterpenes with antihyperglycaemic activity exist in other species such as Rubus crataegifolius, Rubus coreanus, ${ }^{73}$ and Rubus suavissimus. ${ }^{74,75}$ The action of rubusoside on the secretion of insulin can be explained by the antihyperglycaemic effect. $^{76}$ In our study, glucokinin does not contribute to the hypoglycaemic effect because glucokinin was not abundant.

- Buddleja cordata. This plant contains the flavones linarin and vanilic acid which have amoebicidal activity, and contains verbascoside. ${ }^{77}$ No pharmacological studies on the antidiabetic activity of these compounds exist. $^{78}$ However, different extracts in Buddleja polystachya are antihyperglycaemic; the ethyl acetate fraction had the highest hypoglycaemic activity, followed by the dichloromethane fraction, and the nbutanol fraction showed the weakest activity. ${ }^{79}$

- Cecropia obtusifolia exerts hypoglycaemic effectiveness due mainly to isoorientin and chlorogenic acid metabolites, which act by inhibiting alpha-glucosidase activity in vitro..$^{4,30,31}$ The hypoglycaemic activity of the aqueous extract of C. obtusifolia leaves in diabetic rats exhibits an extrapancreatic mechanism. ${ }^{54,80}$ Leaf decoction in diabetic patients also reduced blood glucose levels after 4 weeks of administration; the reduction was significant and persisted until 18 weeks of administration. ${ }^{4,81}$ In the present report a high tannin content in the entire mesophyll of the leaf is characteristic of this species, which is shown in orange/gold in Figure 3 N,O. In addition, glucokinin was observed only in chloroplasts and not in special structures.
Therefore, the antihyperglycaemic activity of this species should be associated mainly with the isoorientin and chlorogenic acid metabolites reported. ${ }^{4,30,31,81,82}$

Whether via a single or several of these aforementioned mechanisms, plants exert hypoglycaemic properties. ${ }^{28}$ The presence of glucokinin in plants can signify an additional mechanism of effective action due to the extra supply of protein similar to insulin. In the present study, the presence of glucokinin was indicated by the positive reaction against insulin during the immunocytochemistry of the species studied. All species reacted in chlorophyll parenchyma, specifically in the chloroplasts, which is supported by the reports of Azevedo et al. $;^{15}$ in cell walls, as has been reported in the seed coat of $V$. unguiculata ${ }^{14}$ and in the seed coat tissue of $C$. ensiformis. ${ }^{83}$ In addition, in $O$. ficus-indica, B. vulgaris and $B$. cordata, crystals were observed that may be made of calcium oxalate as reported for $B$. variegata. ${ }^{15}$ Other species studied showed laticifers, secretory canals or cavities with high glucokinin content, assessed via their immunocytochemical and protein reactions. Petrocelinum crispum, $T$. officinale, $T$. stans, B. vulgaris, G. ulmifolia, R. adenotrichus, and $B$. cordata had laticifers that reacted strongly to glucokinin; $B$. cavanillesii had both laticifers and secretory canals that reacted strongly; and O. ficus-indica had secretory cavities and $A$. vera secretory canals that reacted strongly.

The traditional use of plants to treat DM2 during the early stages of the disease is promising; therefore, understanding the active principles of their therapeutic effects is important. Several of these species, including $O$. ficus-indica, C. obtusifolia, $B$. cavallinesii, $T$. stans, $T$. officinale, and $A$. vera, are currently used in commercial preparations (Diabetea, Diabe-te, Diabetil) for the control of DM2. ${ }^{84}$ The majority of these six species studied strongly reacted to protein corresponding to glucokinin. These species, along with $P$. crispum, B. pilosa, $C$. scolymus, $P$. edulis (synonymous with $P$. aculeata), and B. vulgaris, are included in the Appendix of Antidiabetic Plants of the computer database NAPRALERT, created and maintained by the Program for Collaborative Research in the Pharmaceutical Sciences, College of Pharmacy, University of Illinois at Chicago. ${ }^{85}$

Our objective was to investigate the correlation between the presence of glucokinin and accumulated protein in plant structures used as a remedy for DM2, detected using NBB. This correlation could then serve as a method for detecting hypo- glycaemic plants by the presence of glucokinin.

Although the presence of glucokinin, insulin or insulin-like protein has been demonstrated in prokaryotes, ${ }^{86}$ plants and other species, ${ }^{8,87,88}$ the localisation of glucokinin was unknown until the study performed by Azevedo et al., ${ }^{15}$ who reported the presence of glucokinin in chloroplasts. The present study shows the additional potential of these species as effective treatments for DM2 due to their glucokinin content, which was suggested in $1923 .^{8}$ ) The techniques presented can be used in parallel. The NBB histochemical technique can also be used alone, because it is inexpensive, easy and quick to perform. These techniques could be used to screen for accumulated protein in other medicinal plant species used for the treatment of DM2 to indicate the presence of glucokinin, which would maintain these species as potentially effective at controlling the deleterious effects of DM2 caused by high blood glucose levels, which was proposed by Khursheed et al. ${ }^{86}$ for Spirulina platensis.

\section{References}

1. Eddouks M, Bidi A, Bouhali BE, Hajji L, Zeggwagh NA. Antidiabetic plants improving insulin sensitivity. J Pharm Pharmacol 2014;66:1197-214.

2. Patel, DK, Prasad SK, Kumar R, Hemalatha S. An overview on antidiabetic medicinal plants having insulin mimetic property. Asian Pac J Trop Biomed 2012;2:320-30.

3. Esquivel-Gutiérrez ER, NoriegaCisneros R, Bello-González MA, Saavedra-Molina A, Salgado-Garciglia R. Plantas utilizadas en la medicina tradicional mexicana con propiedades antidiabéticas y antihipertensivas. Biológicas 2012;14:45-52.

4. Aguilar A, Camacho JR, Chino S, Jácquez P, López ME. Herbario Medicinal del Instituto Mexicano del Seguro Social. Información etnobotánica. Instituto Mexicano del Seguro Social, México; 1994; 253 pp.

5. Andrade-Cetto A, Heinrich, M. Mexican plants with hypoglycaemic effect used in the treatment of diabetes. J Ethnopharmacol 2005;99:325-348.

6. Giner Larza EM, Castillo García E. Fitoterapia y diabetes. Revista de Fitoterapia 2003;3:113-22.

7. Silva L, Santos S, Acevedo C, Cruz M, Venâncio T, Cavalcante $\mathrm{C}$, et al. The leaves of green plants as well as a cyanobacterium, a red alga, and fungi 
contain insulin-like antigens. Braz J Med Biol Res 2002;35:297-303.

8. Collip JB. Glucokinin. A new hormone present in plant tissue. Preliminary paper. J Biol Chem 1923;56:513-543.

9. Le Roith D, Shiloach J, Roth J, Lesniak MA. Evolutionary origins of vertebrate hormones: substances similar to mammalian insulins are native to unicellular eukaryotes. Proc Natl Acad Sci USA 1980;77:6184-8.

10. Collier E, Watkinson A, Cleland CF, Roth, J. Partial purification and characterization of an Insulin-like material from spinach and Lemna gibba G3. J Biol Chem 1987;262:6238-47.

11. García Flores C, Aguilar R, Reyes de la Cruz H, Albores M, Sánchez de Jiménez E. A maize insulin-like growth factor signals to a transduction pathway that regulates protein synthesis in maize. Biochem J 2001;358:95-100.

12. Alarcón-Aguilar FJ, Roman-Ramos R, Flores-Saenz JL. Plantas medicinales usadas en el control de la diabetes Mellitus. Ciencia 1993;44:363-81.

13. Oliveira AEA, Machado OLT, Gomes VM, Xavier-Neto J, Pereira AC, Vieira JGH, et al. Jack bean seed coat contains a protein with complete sequence homology to bovine insulin. Protein Pept Lett 1999;6:15-21.

14. Venâncio TM, Oliveira AEA, Silva LB, Machado OLT, Fernandes KVS, Xavier-Filho J. A protein with sequence homology to bovine insulin is present in the legume Vigna unguiculata (cowpea). Braz J Med Biol Res 2003;36: 1167-73.

15. Azevedo C R, Maciel FM, Silva LB, Ferreira ATS, da Cunha M, Machado OLT, et al. Isolation and intracellular localization of insulin-like proteins from leaves of Bauhinia variegata. Braz J Med Biol Res 2006;39:1435-44.

16. Sangeetha M, Vasanthi H. Plant kingdom claims for insulin!!! Sri Ramachandra J Med 2009;1:24-30.

17. Fisher DB. Protein staining of ribboned epon sections for light microscopy. Histochemie 1968;16:92-96.

18. Johansen DA. Plant microtechnique. McGraw-Hill Book Co., Inc., New York; 1940.

19. Ruzin SE. Plant microtechnique and microscopy. Oxford University Press; Oxford, UK; 1999.

20. Henry RR. Insulin resistance: from predisposing factor to therapeutic target in type 2 diabetes. Clin Ther 2003;25:B47-B63.

21. Ozsoy-Sacan O, Yanardag R, Orak H, Ozgey Y, Yarat A, Tunali T. Effects of parsley (Petroselinum crispum) extract versus glibornuride on the liver of streptozotocin-induced diabetic rats. J Ethnopharmacol 2006;104:175-81.

22. Bolkent S, Yanardag R, Ozsoy S, Karabulut B. Effects of parsley (Petroselinum crispum) on the liver of diabetic rats: A morphological and biochemical study. Phytother Res 2004;18; 996-9.

23. Hsu YJ, Lee TH, Chang CLT, Huang YT, Yang WC. Anti-hyperglycemic effects and mechanism of Bidens pilosa water extract. J Ethnopharmacol 2009; 122:379-83.

24. Ubillas RP, Mendez CD, Jolad SD, Luo J, King SR, Carlson TJ, et al. Antihyperglycemic acetylenic glucosides from Bidens pilosa. Planta Med 2000;66:82-3.

25. Alarcón-Aguilar FJ, Roman-Ramos R, Flores-Saenz JL, Aguirre-Garcia F. Investigation on the hypoglycaemic effects of extracts of four Mexican medicinal plants in normal and alloxandiabetic mice. Phytother Res 2002;16: 383-386.

26. Bartolome AP, Villaseñor IM, Yang WC. Bidens pilosa L. (Asteraceae): Botanical properties, traditional uses, phytochemistry, and pharmacology. Evid-Based Compl Alt 2013;2013: 340215.

27. Lai BY, Chen TY, Huang SH, Kuo TF, Chang TH, Chiang ChK, et al. Bidens pilosa formulation improves blood homeostasis and $\beta$-Cell function in men: A pilot study. Hindawi Publishing Corporation Evidence-Based Complementary and Alternative Medicine Volume 2015, 5 pages. Article ID 832314.

28. Chang CLT, Liu HY, Kuo TF, Hsu YJ, Shen MY, Pan CY et al. Anti-diabetic effect and mode of action of cytopiloyne. Evid-Based Compl Alt 2013;2013: 685642 .

29. Lastra Valdés HA, Ponce de León Rego H. Bidens pilosa Linné. Rev. Cubana Plnt Med 2001;1:28-33.

30. Andrade-Cetto A, Wiedenfeld $H$. Hypoglycemic effect of Cecropia obtusifolia on streptozotocin diabetic rats. J. Ethnopharmacol 2001;78:145-9.

31. Andrade-Cetto A, Becerra-Jiménez J, Cárdenas-Vázquez R. Alfa-glucosidaseinhibiting activity of some Mexican plants used in the treatment of type 2 diabetes. J Ethnopharmacol 2008;116: 27-32.

32. Aguilar-Santamaría L, Ramírez G, Nicasio P, Alegría-Reyes C, HerreraArellano A. Antidiabetic activities of
Tecoma stans (L.) Juss. ex Kunth. J Ethnopharmacol 2009;124:284-8.

33. Escandón-Rivera S, González-Andrade M, Bye R, Linares E, Navarrete A, Mata R. $\alpha$-Glucosidasa inhibitors from Brickellia cavanillesii. J Nat Prod 2012;75:968-74.

34. Hernández-Galicia E, AguilarContreras A, Aguilar-Santamaría L, Román-Ramos R, Chávez-Miranda A, García-Vega LM, et al. Studies on hypoglycemic activity of mexican medicinal plants. Proc West Pharmacol Soc 2002;45:118-24.

35. Román-Ramos R, Flores-Sáenz JL, Partida-Hernández G, Lara-Lemus A, Alarcón-Aguilar F. Experimental study of the hypoglycemic effect of some antidiabetic plants. Arch Invest Med (Mex) 1991;22:87-93.

36. De la Paz Naranjo J, Corral Salvadó A, Rivero Jiménez G, Fernández Menéndez M, Pérez Santoya PE. Efecto hipoglicemiante del extracto fluido de Tecoma stans Linn en roedores. Rev Cub Med Mil 2003;32:13-7.

37. Romero-Cerecero O, Reyes-Morales H, Aguilar-Santamaría L, Huerta-Reyes M, Tortoriello-García J. Use of medicinal plants among patients with diabetes mellitus type 2 in Morelos, México. B Latinoam Caribe P1 2009;8:380-8.

38. Hinou J. Polyphenolic substances of Cynara scolymus. Ann Pharm Fr 1989;3:1221-6.

39. Nazni P, Poongodi Vijayakumar T, Alagianambi $\mathrm{P}$ Amirthaveni $\mathrm{M}$. Hypoglycemic and Hypolipidemic effect of Cynara scolymus among selected type 2 diabetic individuals. Pak J Nutr 2006;5:147-51.

40. Azzini E, Bugianesi R, Romano F, Di Venere D, Miccadei S, Durazzo A, et al. Absorption and metabolism of bioactive molecules after oral consumption of cooked edible heads of Cynara scolymus L. (cultivar Violetto di Provenza) in human subjects: a pilot study. $\mathrm{Br} \mathrm{J}$ Nutr 2007;97:963-9.

41. Wang M, Simon JE, Aviles IF, He K, Zheng QY, Tadmor Y. Analysis of antioxidative phenolic compounds in artichoke (Cynara scolymus L.). J Agric Food Chem. 2003;51:601-8.

42. Schütz K, Carle R, Schieber A. Taraxacum - A review on its phytochemical and pharmacological profile. Review Article. J Ethnopharmacol 2006;107:313-23.

43. Zhu X, Zhang H, Lo R. Phenolic compounds from the leaf extract of artichoke (Cynara scolymus L.) and their antimicrobial activities. J Agric Food 
Chem 2004;52:7272-8.

44. Akhtar MS, Khan QM, Khaliq T. Effects of Portulaca oleracae (Kulfa) and Taraxacum officinale (Dhudhal) in normoglycaemic and alloxan-treated hyperglycaemic rabbits. J Pak Med Assoc 1985;35:207-10.

45. Hussain Z, Waheed A, Qureshi RA, Burdi DK, Verspohl EJ, Khan N, et al. The effect of medicinal plants of Islamabad and Murree region of Pakistan on insulin secretion from INS1 cells. Phytother Res 2004;18:73-7.

46. Petlevski R, Hadzija M, Slijepcevic M, Juretic D. Effect of 'antidiabetis' herbal preparation on serum glucose and fructosamine in NOD mice. J Ethnopharmacol 2001;75:181-4.

47. Petlevski R, Hadzija M, Slijepcevic M, Juretic D, Petrik J. Glutathione S-transferases and malondialdehyde in the liver of NOD mice on short-term treatment with plant mixture extract P9801091. Phytother Res 2003;17:311-4.

48. Hänsel R, Kartarahardia M, Huang JT, Bohlnann F. Sesquiterpenlacton- $\beta$-Dglucopyranoside sowie ein neues eudesmanolid aus Taraxacum officinale. Phytochemistry 1980;19:857-861.

49. Hausen BM. Taraxinsäure-1'-O- $\beta$-Dglucopiranosid das kontaktallergen des löwenzahns (Taraxacum officinale Wiggers). Derm Beruf Umwelt 1982;30 51-3.

50. Rauwald H, Huang JT. Taraxacoside, a type of acylated gammabutyrolactone glycoside from Taraxacum officinale. Phytochemistry 1985;24:1557-9.

51. Pérez RM, Pérez C, Zavala MA, Pérez $\mathrm{S}$, Hernández $\mathrm{H}$, Lagunes $\mathrm{F}$. Hypoglycaemic effects of lactucin-8-Omethylacrylate of Parmentiera edulis fruit. J Ethnopharmacol 2000;71:391-4.

52. Pérez-Gutiérrez RM, Pérez-González C, Zavala-Sánchez MA, Pérez-Gutiérrez S. Actividad hipoglucemiante de Bouvardia terniflora, Brickellia veronicaefolia y Parmentiera edulis. Salud Pública de México 1998;40:354-8.

53. Frati Munari AC, Vera Lastra O, Ariza Andraca CR. Evaluación de cápsulas de nopal en la diabetes mellitus. Gac Med Mex 1992;128:431-6.

54. Garibay Bagnis C, San Martín Martínez E. Estudio del efecto hipoglucémico de algunas plantas utilizadas en México para el control de la diabetes. Rev. Salud Pública Nutr. Edición Especial 2006;11:28-33.

55 Becerra-Jiménez J, Andrade-Cetto A. Effect of Opuntia streptacantha Lem. on alpha-glucosidase activity. Ethnopharmacol 2012;139:493-6.
56. Ozsoy-Sacan O, Karabulut-Bulan O, Bolkent S, Yanardag Frati R, Ozgey Y. Effects of chard (Beta vulgaris L. var cicla) on the liver of the diabetic rats: a morphological and biochemical study. Biosci Biotechnol Biochem 2004;68:1640-8.

57 Gezginci-Oktayoglu S, Sacashern O, Bolkent S, Ipci Y, Kabasakal L, Sener $\mathrm{G}$, et al. Chard (Beta vulgaris L. var. cicla) extract ameliorates hyperglycemia by increasing GLUT2 through Akt2 and antioxidant defense in the liver of rats. Acta Histochem 2014;116: 32-9.

58. Bolkent S, Yanardağ R, TabakoğluOğuz A, Ozsoy-Saçan O. Effects of chard (Beta vulgaris L. var. Cicla) extract on pancreatic B cells in streptozotocin-diabetic rats: a morphological and biochemical study. J Ethnopharmacol 2000;73:251-9.

59. Kabir AU, Samad MB, Ahmed A, Jahan MR, Akhter F, Tasnim J, et al. Aqueous fraction of Beta vulgaris ameliorates hyperglycemia in diabetic mice due to enhanced glucose stimulated insulin secretion, mediated by acetylcholine and GLP-1, and elevated glucose uptake via increased membrane bound GLUT4 transporters. PLoS One 2015; 10:e0116546.

60. Ninfali P, Bacchiocca M, Antonelli A, Biagiotti E, Di Gioacchino AM, Piccoli $\mathrm{G}$, et al. Characterization and biological activity of the main flavonoids from Swiss Chard (Beta vulgaris subspecies cycla). Phytomedicine 2007;14:216-221.

61. Kim K, Kim H, Kwon J, Lee S, Kong $\mathrm{H}$, Im SA, et al. Hypoglycemic and hypolipidemic effects of processed Aloe vera gel in a mouse model of noninsulin-dependent diabetes mellitus. Phytomedicine 2009;16:856-63.

62. Alonso-Castro AJ, Salazar-Olivo LA. The anti-diabetic properties of Guazuma ulmifolia Lam are mediated by the stimulation of glucose uptake in normal and diabetic adipocytes without inducing adipogenesis. J Ethnopharmacol 2008;118:252-6.

63. Tanaka M, Misawa E, Ito Y, Habara N, Nomaguchi $K$, Yamada $M$, et al. Identification of five phytosterols from Aloe vera gel as anti-diabetic compounds. Biol Pharm Bull 2006;29:1418-22.

64. El Sayed AM, Ezzat SM, Khalil MN, El-Hawary SS. Chemical composition and evaluation of possible alpha glucosidase inhibitory activity of eight Aloe species. J Med Plants Res 2016;10:167-78.

65. Devaraj S, Yimam M, Brownell LA,
Jialal I, Singh S, Jia Q. Effects of Aloe vera supplementation in subjects with prediabetes/metabolic syndrome. Metab Syndr Relat Disord 2013;11:35-40.

66. Huseini HF, Kianbakht S, Hajiaghaee R, Dabaghian FH. Anti-hyperglycemic and anti-hypercholesterolemic effects of Aloe vera leaf gel in hyperlipidemic type 2 diabetic patients: a randomized double-blind placebo-controlled clinical trial. Planta Med 2012;78:311-6.

67. Adnyana IK, Yulinah E, Yuliet, Kurniati NF. Antidiabetic activity of aqueous leaf extracts of Guazuma ulmifolia Lamk., ethanolic extracts of Curcuma xanthorrhiza and their combinations in Alloxan-induced diabetic mice. Res J Med Plant 2013;7:158-64.

68. Lemus I, García R, Delvillar E, Knop G. Hypoglycemic activity of four plants use in Chilean popular medicine. Phytother Res 1999;13:91-4.

69. Novaes AP, Rossi C, Poffo C, Pretti Junior E, Oliveira A, Schlemper V, et al. Preliminary evaluation of the hypoglycemic effect of some Brazilian medicinal plants. Therapie 2001;56: 427-30.

70. Kanegusuku M, Benassi JC, Pedrosa RC, Yunes RA, Filho VC, Maia AA, et al. Cytotoxic, hypoglycemic activity and phytochemical analysis of Rubus imperialis (Rosaceae). Z Naturforsch C 2002;57:272-6.

71. Alonso R, Cadavid I, Calleja JM. A Preliminary study of hypoglycemic activity of Rubus fruticosus. Planta Med 1980;40:102-6.

72. Jouad H, Maghrani M, Eddouks M. Hypoglycaemic effect of Rubus fructicosis L. and Globularia alypum L. in normal and streptozotocin-induced diabetic rats. J Ethnopharmacol 2002;81: 351-6.

73. Choi JW, Yoo YM, Kim MY, Nam JH, Nugroho A, Park HJ. Anti-hyperglycemic and Anti-hyperlipidemic Effects of the triterpenoid-rich fractions from Rubus coreanus and Rubus crataegifolius and their main component, Niga-ichigoside $\mathrm{F}_{1}$, in streptozotocin-induced diabetic rats. Nat Prod Sci 2008; 14:260-4.

74. Wang Y, Gong C, Tian J, Shao S, Fan B, Liu J. Purification of rubusoside from Tongshan Rubus suavissimus. J Public Health Prev Med 2008;19:23-4.

75. Ma J, He WW, UZ. Progress on rubusoside in Rubus suavissimus S. Lee $(\mathrm{J})$. Food Drug 2008-05.

76. Tian C, Zuo W, Sun B, Li M, Wang H, Huang X. Effect of rubusoside extracts on hyperglycemic rats induced by strep- 
tozotocin. Acta Nutrimenta Sinica. 2003-01:29-33.

77. Camacho M, Hernandez P, Morfín L. Tepozan (Buddleja cordata). Proyecto PAPIME PE205907. FESC-UNAM; México; 2009.

78. CONABIO, 2010. Buddleja cordata. Available from: http://bios.conabio. gob.mx/especies/6033927.pdf

79. Al Ati HY, Fawzy GA, El Gamal AA, Khalil AT, El Din El Tahir K, AbdelKader MS, et al. Phytochemical and biological evaluation of Buddleja polystachya growing in Saudi Arabia. Pak J Pharm Sci 2015;28(4 Suppl): 1533-40.

80. Almanza Pérez J, López Cruz E, Vázquez Carrillo L, Banderas Dorantes T, Roman Ramos R, Alarcón Aguilar F. Efecto de extractos vegetales obtenidos de 5 plantas antidiabéticas sobre los niveles de glucosa e insulina en ratones sanos y diabéticos. Proceedings 2nd Nat. Congr. Química Médica; México; p. 17-21.

81. Revilla-Monsalve MC, Andrade-Cetto A, Palomino-Garibay MA, Wiedenfeld $\mathrm{H}$, Islas-Andrade S. Hypoglycemic effect of Cecropia obtusifolia Bertol aqueous extracts on type 2 diabetic patients. J Ethnopharmacol 2007;111: 636-40.

82. Alonso-Castro AJ, Miranda-Torres AC, González-Chávez MM, Salazar-Olivo LA. Cecropia obtusifolia Bertol and its active compound, chlorogenic acid, stimulate 2-NBDglucose uptake in both insulin-sensitive and insulin-resistant 3T3 adipocytes. J Ethnopharmacol
2008;120:458-64.

83. Xavier-Filho J, Oliveira AEA, Silva LB, Azevedo CR, Venancio TM, Machado OLT, et al. Plan Insulin or glucokinin: a conflicting issue. Braz J Plant Physiol 2003;15:67-78.

84. Johnson L, Strich H, Taylor A, Timmermann B, Malone D, TeufelShone N, et al. Use of herbal remedies by diabetic Hispanic women in the southwestern United States. Phytother Res 2006;20:250-5.

85. Marles RJ, Farnsworth NR. Antidiabetic plants and their active constituents. Phytomedicine 1995;2:137-89.

86. Khursheed S, Anwer R, Fatma T. Insulin like antigen: Sources other than pancreas. Int J Curr Pharm Res 2012; 4:24-8. 